\title{
The lost memory of industrial places: the Ipanema blast furnace
}

\author{
M. Balzani ${ }^{1}$, L. Rossato ${ }^{1}$ \\ ${ }^{1}$ University of Ferrara Department of Architecture, marcello.balzani@unife.it, luca.rossato@unife.it
}

\section{Commission II}

KEY WORDS: industrial cultural Heritage, 3D documentation, 3D analyses, blast furnaces, Brazil,

\begin{abstract}
:
This contribution is based on a joint research project developed by the University of Ferrara, Department of Architecture (Italy) and the Escola Politecnica USP of São Paulo (Brazil) by the which it was possible to scan the interior and exterior surfaces of the ancient blast furnaces of São João do Ipanema, an extraordinary example of industry of cast iron production of the XIX century.

The research was aimed at investigating the evolution of the blast furnace technique exploring a surprisingly rich Brazilian technical literature, with description records and drawings dated between the late 19th and early 20th centuries. Beside historical documentation it was also implemented on site a 3D survey campaign of the furnaces to understand how the profiles were modified along the time. The first outputs of the project were thus focused on the evaluation of the transformation of the equipment in terms of more efficient shapes able to enhance the relationship between blast furnace profile fuel consumption and productivity.

The use of accurate digital technology, the following CAD elaboration of the chimney, the $3 \mathrm{~d}$ model and the comparison with XIX century technical drawings confirmed that European directors of the plant were familiar with the most advance technical and scientific procedures and brought to the site a great technological improvement by an innovative know-how.
\end{abstract}

\section{INTRODUCTION}

In 2017 before the current pandemic emergency, the DIAPReM research centre (Department of Architecture, University of Ferrara, Italy) was asked to contribute along with the Polytechnic School of USP (Sao Paulo, Brazil) to the analyses of the interior and exterior surfaces of the residual part of the blast furnaces of the São João do Ipanema, Iperò, Sao Paulo state, Brazil (Figure 1). São João do Ipanema, one of the few remains in Brazil of the industrial production of iron, dates back to the 15th century (Felicíssimo, 1969). The industry operated in Brazil between 1810 and 1926.

The work is based on the literature produced in that century about the Ipanema Ironworks, the technical reports written by the army and the government, and articles published in magazines and newspapers, compared with contemporary international literature. By the digital survey techniques applied the research team was able to generate more information about the furnaces in their current state of conservation. This work deals primarily with one aspect that was reported and discussed several times by international experts. the shape of the void inside the blast furnace, its architecture and the resulting profile.

This explains why digital documentation activities by means of laser scanner technology was focused to understand the last steps of the transformations of the original chimney profiles (built in 1817 by engineer Frederico Varnhagen). These profiles were modified to improve the productivity of the site, as measured by the indicator used until today by the steel industry (Telles, 1993). The shape modification improved the relationship between fuel consumption and productivity and were conceived by the European directors of the plant that were familiar with the most advance technical and scientific procedures of that period (Dupre, 1885; Landgraf et al. 2015).

The importance of the site for the history of steel industry in Brazil is underlined by the work developed by the International Committee for the Conservation of the Industrial Heritage $\mathrm{ICCIH}$ (an international group dedicated to industrial archaeology and heritage) that is focusing some research activities on blast furnace plants in cooperation with ICCROM, bringing to the discussion many sites worthy of documentation and conservation in terms industrial heritage (Douet, 2013). As
Cultural Heritage, these industries include both tangible (equipment, buildings) and intangible aspects (technical knowhow, traditional techniques) that should be preserved and transferred to future generation. This places, if properly documented and studied, could become venues of knowledge and memory, where it could be possible to organize technical visits for scholars and experts. The valorisation of the achievement in the field of steel production of that time can be describe by digital technologies through virtual reconstruction, augmented reality and other techniques (Morrison et al., 2012)

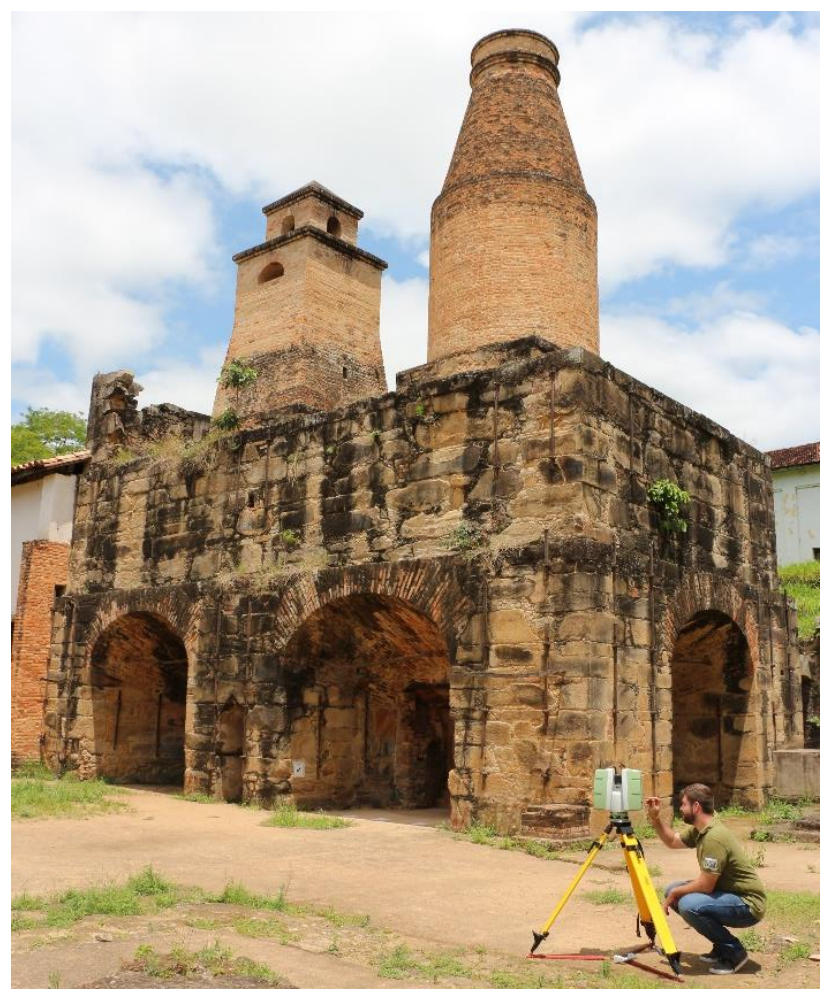

Figure 1: the blast furnaces under digital documentation process 


\section{THE BLAST FURNACE IN SÃO JOÃO DO IPANEMA}

\subsection{The Iron century}

The period from 1801 to 1900 is known as the "Iron Century." This material's consumption increased from less than one million tons per year to more than 40 million worldwide. The conveyance of people and products was revolutionized by industry, railways, and steam navigation. Gas lighting, piped water, and sewage, all made possible by iron pipes, revolutionized cities. The Sainte Geneviève Library in Paris and the Crystal Palace at the London World Exhibition, both cast-iron constructions erected in 1851, exhibited the architecture and construction technologies of the day. Cast-iron sculptures, lampposts, kiosks, and seats, offered in catalogues, became more sophisticated, and they spread to practically every city on the earth. Cast-iron fences have been supplanted with cast-iron fences.

The kitchen was altered, and wrought iron cutlery, cast iron pans, and cookers became popular. Even in clothing, iron appeared, along with the fer de Berlin gems. Small forges in Minas Gerais manufactured agricultural equipment, iron levers, and diggers for mining (Landgraf, 2021).

\subsection{Blast furnace in $19^{\text {th }}$ century}

During $19^{\text {th }}$ century blast furnaces were typically over eight meters high and had a large inner void in the form of two cone trunks joined at the largest diameter which was about 2 meters in diameter. It may look like it, but it is not a chimney

The dimensions are estimated on the basis of empirical formulas and previous experience, which takes into account the operating conditions, for example the type of charge it will receive. As identified by the extended research activity of the group led by Prof. F.J.G. (Escola Politecnica USP, São Paulo, Brazil)) Landgraf the Karsten's Steelmaking Manual is one of the main source for this investigation. The book became so famous that it was quoted by several of Ipanema's directors (Araujo et al., 2017). The most used shaped for blast furnaces are described Karsten and summarize in Figure 2.

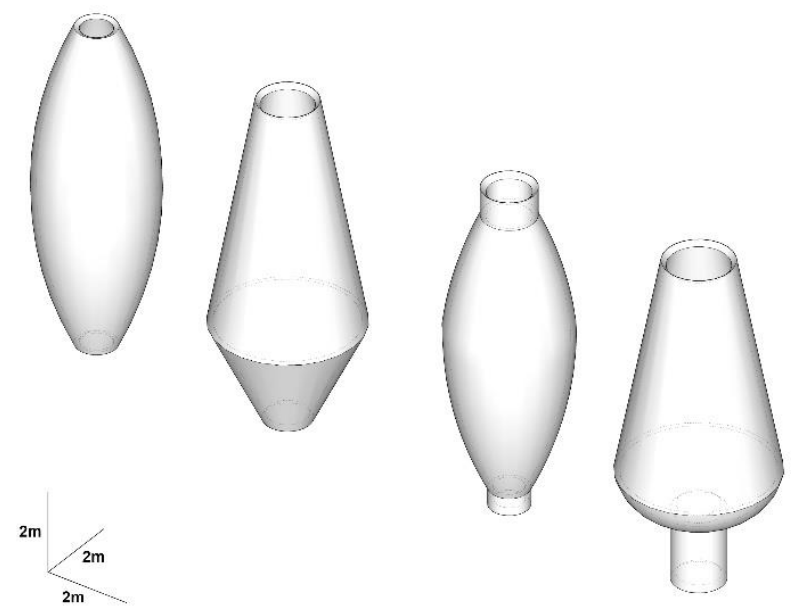

Figure 2: Three dimensional analyses of blast furnace interior surface (non-dimensional thickness) of the main typology in use during XIX century. These shapes were utilized before the great improvement by new technologies applied to the field of iron production at large scale (elaboration by the authors based on historic drawings available in System Der Metallurgie: Geschichtlich, Statistisch, Theoretisch Und Technisch, Fuenfter Band by Carl Johann Bernhard Karsten).

\subsection{The Ipanema site}

The Fábrica de Ferro de Ipanema, in São Joas do Ipanema, was a central Luso-Brazilian government operation that began shortly after the arrival of the Portuguese royal family in Brazil, went through ups and downs throughout the empire, and finally closed in the Republic.

It has been seen as strategic or a huge financial drain for more than a century. It was under military control for the majority of this time before being handed over to the government.

Between 1878 and 1890, the Ministry of Agriculture was at the height of its activity.

It had times of great investment and times when not even salaries were paid. The logistics of distributing the 100 to 300 tons of iron/year was considered a major obstacle to its success (Landgraf, 2021).

However, the advent of Sorocabana's rails in 1879 did not result in a substantial change in demand, as the expansion of the railway network lowered the cost of imported iron for the entire market. Continuously operating blast furnaces entailed arduous activities, which the successive employment of employees from Germany, Austria, and later Italy over the nineteenth century did not totally solve. The basic material, which was formerly thought to be endless, also had its drawbacks.

It was difficult to get a consistent supply of charcoal, and the presence of magnetitic iron ore may have hampered the process, but not the product quality.

In the Brazilian state of Minas Gerais, private initiative finally saw the chance to invest in this type of business. Military engineers were primarily in charge of the Ipanema Ironworks. Even though the Factory had demonstrated the technical feasibility of operating a steel mill in the tropics, and despite the fact that the world demand for iron grew enormously as a result of steam engines, railways, ships, and the use of iron in construction and architecture, and despite the fact that iron smelting was a thriving nineteenth-century Brazil, no Brazilian businessman dared to invest in the industry's raw material.

The Baron of Mauá made a lot of money in the foundry business, as well as the English in Recife and Rio de Janeiro, and German immigrants in S. Paulo but always using pig iron ingots as raw material imported predominantly from the United Kingdom. As far as we know, only the foundry of the Arsenal of the Navy in Rio de Janeiro used pig iron produced in Ipanema (Landgraf et al., 2016).

The equipment worked as follows: ore and coal were added from above and took hours to descend from the top to the bottom, where the crucible was located and where the liquid iron, while air was blown in through a tube called gibberish, placed only 0.5 meters from the base, reacted with the coal in order to form gases that raised to the top The coal, which was introduced at the top, reacted with the gases as it descended, eventually combusting with the air injected by the bellows. The incomplete combustion of coal produced gases that reacted chemically with the iron ore, carrying oxygen from its chemical composition upwards. For this reason the furnace shape has been always correlated to its function.

Blast furnaces are still the primary means of producing metallic iron today. It still has two inverted cones and a base in its interior void but along the time the height of the blast furnace expanded four times over time to accommodate the rise in daily production, while the diameter of the base increased 28 times (Figure 3 ).

The search to raise the furnace's productivity, i.e., the amount of liquid iron generated per day, from 1 to 15,000 tons, drove the evolution of the profile alteration. Since the 18th century, the shape of the interior vacuum has been the subject of debate in writings and scientific discussion. 


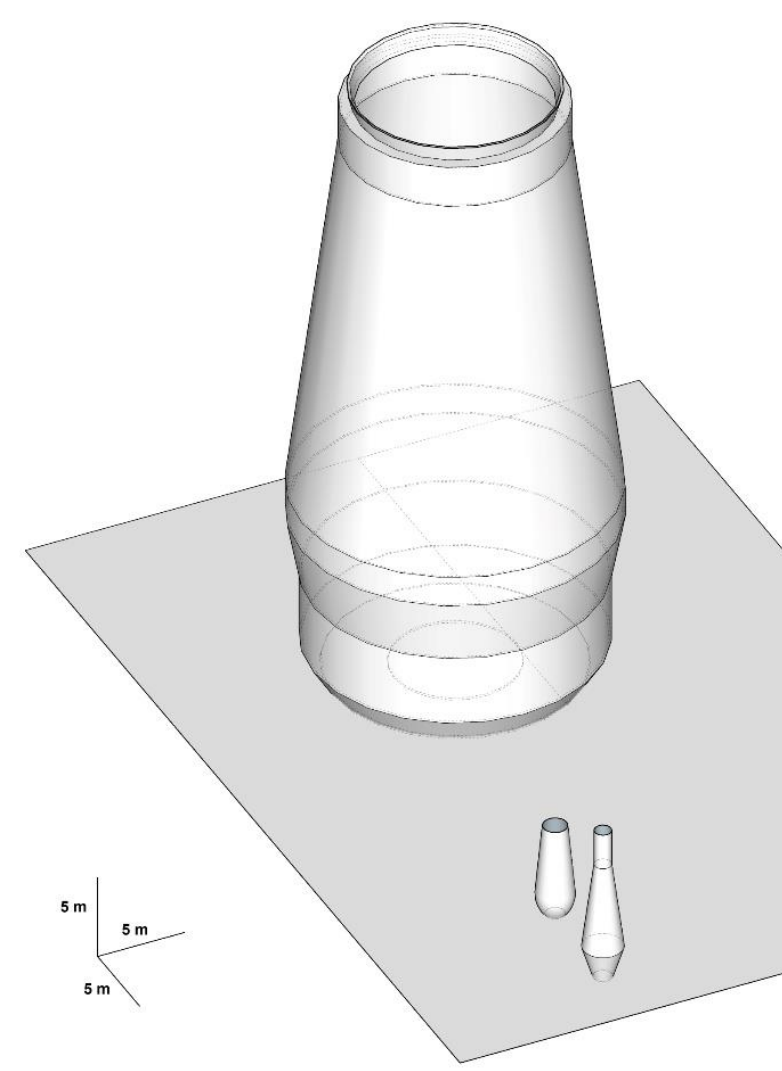

Figure 3: a contemporary blast furnace and the ones at Ipanema factory at the same scale: the height of the blast furnace expanded four times over time to accommodate the rise in daily production, while the diameter of the base increased 28 times (graphic elaboration by the authors based on the work of Prof. Landgraf research team).

\section{INDUSTRIAL CULTURAL HERITAGE}

\subsection{International framework}

Industrial heritage associated with political, economic, cultural, social, scientific, technological, and architectural fields has been a crucial concern to nations and governments, since it reveals the way our ancestors lived, records technical progress and realizes cultural continuity (Liu et al., 2018).

The acknowledgement of industrial heritage by national and international governments, as well as the scientific community, is the consequence of a development process in the field of industrial archaeology that began in the 1970s.

This acknowledgement was endorsed by the intervention of UNESCO and ICOMOS, which opened the way for scientific debate and provided the first universal application guidelines for the preservation of this portion of cultural heritage (Vitale, 2012). The official documents that identify a common thread in Europe and worldwide were then edited by TICCIH (The International Committee for The Conservation Of The Industrial Heritage), the main international association that deals with the conservation and enhancement of industrial heritage. These documents are the Nizhny Tagil Charter for the Industrial Heritage of 2003, the Dublin Principles (ICOMOS - TICCIH, Principles for the Conservation of Industrial Heritage Sites, Structures, Areas and Landscapes) adopted at the 17th General Assembly of ICOMOS in Paris in 2011 and the Taipei Declaration for Asian Industrial Heritage of 2012 (De Bernardinis et al., 2019).
Whereas the cultural discussion on new uses and modes of fruition of disused industrial artefacts is becoming increasingly important on a global scale - enriched by methodologies that go beyond conservation and valorisation to the much more "in vogue" areas of energy efficiency and sustainable development (Ifko, 2016) - local policy does not succeed in translating this ferment into rules and regulations that can serve as a guide and stimulus for redevelopment according to compatibility criteria, which comply with international principles of protection while reinterpreting them at national level to adapt to specific contextual needs (De Bernardinis et al., 2019).

Governments and scientific research have focused their attention on cognitive paths, inventory and cataloguing sheets with various types of surveys, functional recovery of the monument as an alternative to various forms of restoration, and analysis of the characteristic elements since the recognition of workplaces as industrial heritage to be protected. Essential to the identification and protection of historic industrial sites was their documentation and understanding. This has been achieved by a variety of means by the national recording agencies, by recording under the provisions of the Planning legislation and by recording by enthusiasts (Falconer, 2006).

If inventories and catalogues are the primary tools of knowledge utilized in the process of industrial archaeology investigation, reasoning in terms of legacy valorisation proposes alternative reuse approaches.

In the topic of industrial archaeology, factory reuse can take place on a variety of scales and using a variety of methodologies. Of course, not all of them are consistent with conservation principles and practices, and, more importantly, with the transmission of cultural and historical memory in accordance with a deliberate historiographic aim.

Theoretically, we should only discuss the transformation of industrial archaeological evidence to Cultural Heritage in the latter scenario, because in the other cases, while acceptable, we are dealing with 'other' forms of regeneration (Parisi, 2009).

In this context, the process of conversion of abandoned industry to Cultural Heritage sites is therefore considered as a procedure that does not end with the recognition of the testimonial value of the building, but is only legitimate when its reuse is completed, understood as the recovery and enhancement of the material and immaterial historical heritage that the protected asset expresses (De Bernardinis et al., 2019).

\subsection{Protection and valorisation of disused blast furnaces}

Some abandoned blast furnaces with substantial remains are included in international lists of historic blast furnaces that have been preserved. Usually, the furnaces are being conserved in a park or museum, or as a place that will be open to the public in the future.

While monument preservation of blast furnaces has a long history, the notion of 20th-century mass production blast furnace installations as industrial heritage is a relatively new tendency. For a long time, it was standard procedure for a disused blast furnace to be removed and replaced with a newer, better one, or for the entire site to be razed to create room for future usage of the region. Several countries have only recently grasped the importance of this Cultural Heritage as part of industrial history. In terms of preservation projects, the first blast furnace not to be dismantled was in Starachowice, Poland (decommissioned in 1968), followed by Yahata Steel Works' last blast furnace in Yahatahigashi-ku, Kitakysh, Japan (decommissioned in 1972) and the "Carrie Furnaces" in Homestead, Pennsylvania (decommissioned in 1978). One of the two blast furnaces at Neunkirchen, Germany (decommissioned in 1982), was the first 
blast furnace in the world to be actively repaired for preservation purposes (Source UNESCO/TICCIH web sites).

The degree of accurate preservation versus incorporation into new structures, or even repurposing, varied amongst the numerous sites for 20th-century mass manufacturing blast furnaces. Generally, the preservation approach towards these sites is divided into many parts, including the conservation of the site itself, its protection as a historical site, and its protection as a cultural site.

\section{RELATED WORKS}

\subsection{Digital documentation of disused industrial sites}

In recent decades the phenomenon of deindustrialisation has been very strong in some areas, and the "voids" left by the operation and vitality of factories have more often become a problem than an opportunity. On the other hand, several generations are needed to reconsider "some spaces as new places", to raise the attention, to take care and valorise the almost lost "memory" of industrial sites (Castronovo, 1980). Nowadays the increased interest in industrial remains has fostered renovation, redevelopment, and new uses that can often bring a real enrichment to the area in which they are located (Spaziante 2008). The potentials of the Ipanema Industries, in terms of cultural site for the preservation of the memory of its iron production age, are huge but only deepening the knowledge on its glorious past it will be possible to elaborate an effective management plan. Furthermore, nowadays, industrial cultural heritage sites benefit digital technologies and 3D data, as a many extra information can be delivered to the user before and during the visit. This set of data can be used to produce 3D HBIM and multimedia information able to visualize virtual reconstructions, as well as 3D animations (La Duca, 2018). The potential of immersive visualization techniques could offer a virtual tour of the an industrial site and the chance to explore it from a technical standpoint: by using immersive visualization technology, operators can improve their understanding of the structures and obtain real-time information about the function (Fassi, 2016). Even though efforts have been committed to investigate the application of digital technologies on industrial cultural heritage areas, a paradigm to define what they should offer in order to support the preservation and enhancement of these sites still misses.

\subsection{A first pilot project in Brazilian territory}

In 2013, less than 10 kilometres far from the historic centre, it was discovered the presence of uncertain ruins of a robust structure composed of stone masonry and mud, which had been nearly completely taken over by plants. After a fast on-site traditional documentation (by paper, notepad, and camera) it remained the challenge of a proper survey to understand in a more accurate way the size of the structure and its components. It was only later, using laser scanner equipment Leica C10, that it was possible to study the exact dimension and morphology of the structure. The documentation campaign was carried out in one day on site, through the complicated site conditions and impenetrable vegetation of the forest by the staff of the DIAPReM centre (Architecture Department of the University of Ferrara). The elaboration of the point cloud allowed some more accurate evaluations about the possible narrative of this structure. The outstanding work by the historian Francisco de Carvalho Dias de Andrade, who documented the whole remain by amazing hand drawings and some measures, was a strong base for the graphic output of the research aimed at validating the theory of Francisco Andrade about the use of the structure as an old mill built in the first part of XVII century (Andrade, 2015).
Only by maintaining a regular interaction across academic fields (as well as between the university and preservation organizations) we will be able to make these old industrial places more understandable.

If it were a mill, it would definitely be an odd sample, similar to the old cornmeal mills that once dotted rural areas across southcentral Brazil. Furthermore, the mills are generally always constructed of lath and plaster - they are fundamentally a carpentry project, and it is very rare to heard of a little cornmeal mill that needs to be built with cyclopean stone masonry like in this case.
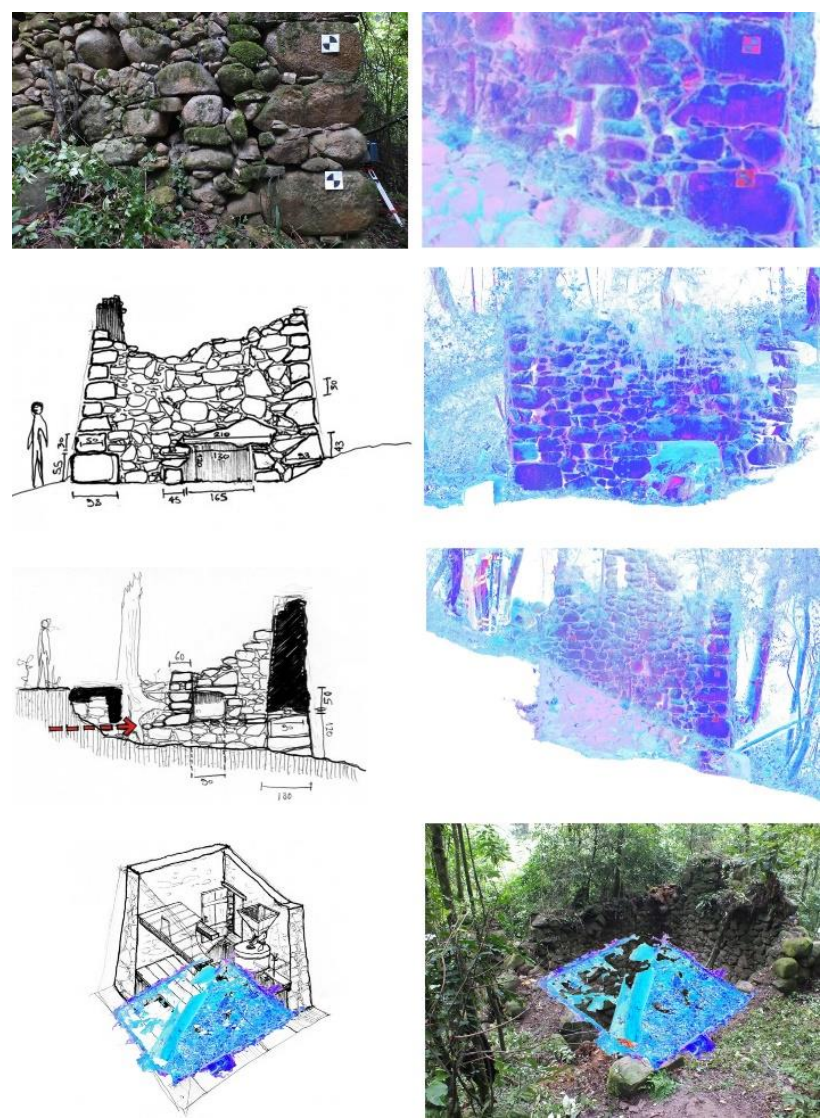

Figure 4: data analyses by point cloud (cyclone software) based on pictures and hand drawings by historian Francisco de Carvalho Dias de Andrade who developed the first hypothesis about the use of the old structure as a mill. It's an unusual carpentry project to come upon a small cornmeal mill that requires cyclopean stone construction, like this one does.

\section{RESEARCH DESIGN}

The iron shortage caused by the First World War led the Brazilian Federal Government to reopen the plant and reinvest in it in 1917 after a closing period. The new age brought reform the raising of the north blast furnace to eleven meters, as can be seen today by the height of the loading door at the back of the furnace.

Little is known about the operation of the blast furnaces during this period (Martins Araujo et al., 2017).

It is known a survey of the remnants of the blast furnaces in 1974, but the profile of the northern blast furnace was incorrectly drawn, imagining it like the southern blast furnace. The interior void of the twin furnaces was determined with this study by means of laser scanning along a one-day campaign on site (Figure $5)$. 


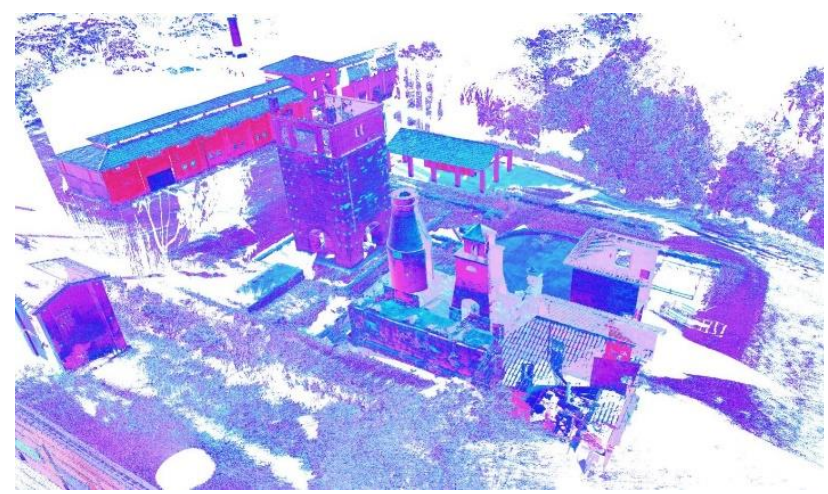

Figure 5: point cloud elaboration of the scanned area at Ipanema factory (in the centre, are visible the two furnaces and their external shape).

The $3 \mathrm{~d}$ database allowed to reconstruct the cut profiles based on the information from this scan.

The size, the volumetric articulation of the survey areas, the surface characteristics and the particular construction conditions directed the survey project towards a multiple methodological integration:

1) 3D scanner survey aimed at generating a point cloud model; 2) detailed topographical survey of the homology points only for the definition of a grid to support the scanning;

3) high-resolution photographic survey aimed at documenting both the overall and detailed state of conservation of the asset.

The stationing points were selected so that the individual scans could collect the greatest amount of metric information and the greatest number of homology points (targets), subsequently allowing for better alignment during the recording phase.

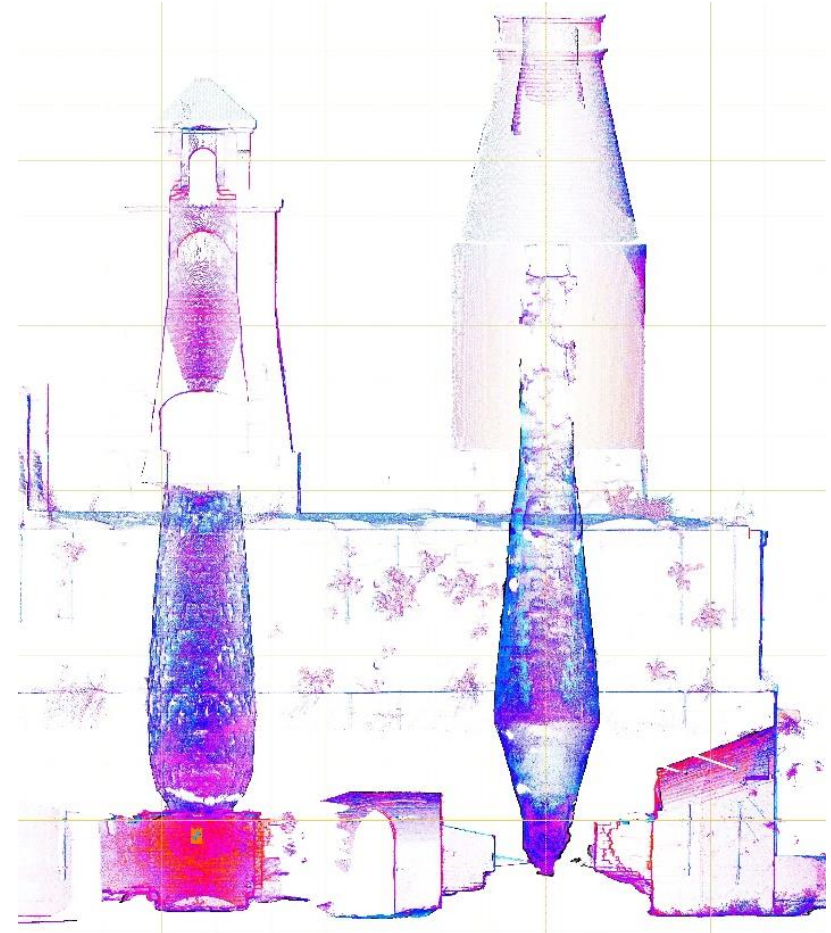

Figure 6: point cloud database sections of the two furnaces analysed.

The three-dimensional survey was carried out using a Leica P20 scanner (speed: $1 \mathrm{mln}$ points/s; accuracy on single measurement: $3 \mathrm{~mm} / 50 \mathrm{~m}$; linear error $<1 \mathrm{~mm}$; standard deviation: up to
$2 \mathrm{~mm} / 50 \mathrm{~m}$; maximum acquisition distance: $120 \mathrm{~m}$ ). While no particular difficulties were encountered in acquiring data from the external portions, great attention was paid to the sealed smoke duct (strictly accessible from the inlet) to achieve a good survey of the inner void (Figure 6)

The stationing did not take place in the traditional manner, but it was necessary to introduce the instrumentation into a hole of adequate size for the passage of the instrument alone. Therefore, in order to reduce the natural vibrations of the equipment, it was necessary to increase the acquisition time of the instrument. The average scanning resolution on the object is $1 \mathrm{pt}$ every $2 \mathrm{~mm}$, while on the targets (homology points) the resolution is 4 pt every $2 \mathrm{~mm}$. A total of 51 scans were carried out, of which 9 general and 42 detailed, measuring the coordinates of $656,901,491$ points. The alignment phase allowed the registration and fusion of the data: the resulting 3D model is populated by millions of points (each defined by a xyz coordinate) which are referred to a local coordinate system. In addition, individual points have a specific reflectance value. Despite the logistic challenges the inner surface of the two furnaces were registered correctly and modelled to start some preliminary evaluations (Figure 7).

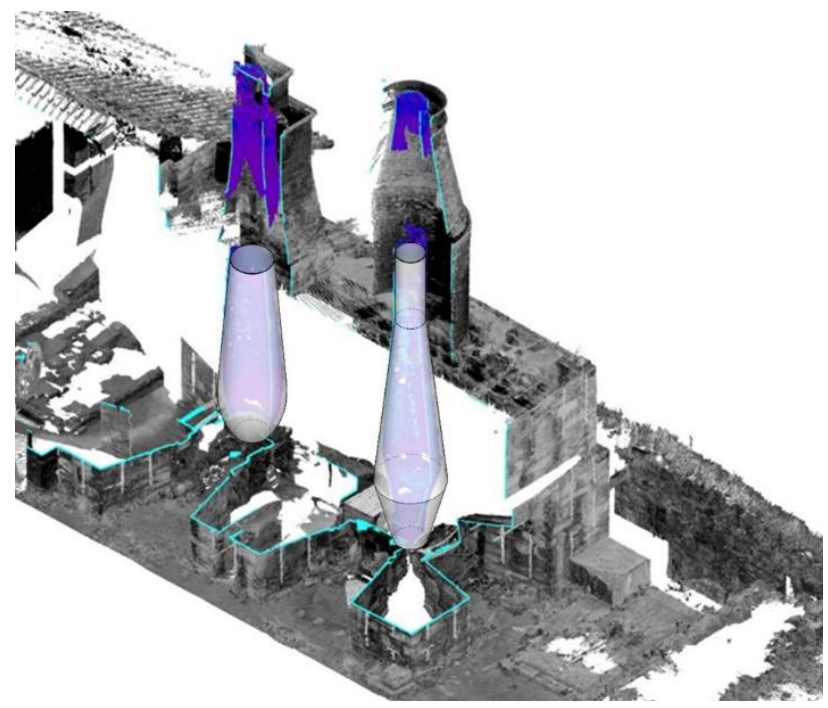

Figure 7: modelling phase of the two inner surface of the blast furnaces starting from the data collected by the digital campaign and later elaborated with alignment and cleaning procedures.

\section{RESULTS}

The acquired point cloud allows the creation of an "identity card" of this industrial cultural heritage buildings, defined in digital support, which will guarantee the processes of restoration, monitoring, enhancement, and protection.

The nineteenth century was a time of vigorous technical experimentation around the world, in the face of challenges and the empirical search for solutions. One such area of experimentation is the profile of the void inside the blast furnace. It was not an easy subject for research because each new profile had to be tested for years and many other factors influenced the performance indicators' outcomes. Nonetheless, Ipanema's engineers experimented, scouring the literature and consulting worldwide consultants for the best approach to boost the furnace's productivity in order to ensure the company's economic viability. By the 3D analyses and database elaboration it was possible to accurately define the profile of the "south oven" (Figure 6 - left side) the which shows the vat, the belly and the upper part of the of the ramp. The lower part of the ramp is at risk 
of collapsing. The maximum width was slightly increased to 2.1 metres. The upper part of the ramp is 3 meters high, in the same position as the profiles of 1865 e 1885 . The gullet is much larger than that of many other furnaces (Figure 9). On the other hand, the profile of the interior void of the "north oven", (Figure 6 right side) is very different, and has implications on its external shape, still well visible today. The internal void of the blast furnace was raised to 11.3 meters, the ramp is steeper but has no belly and the shape of the vat has a conical and a cylindrical segment.

The final elaboration of this shapes by 3D modelling led to an accurate model of the two structures confirming some hypothesis on the construction period and design techniques (Figure 8).

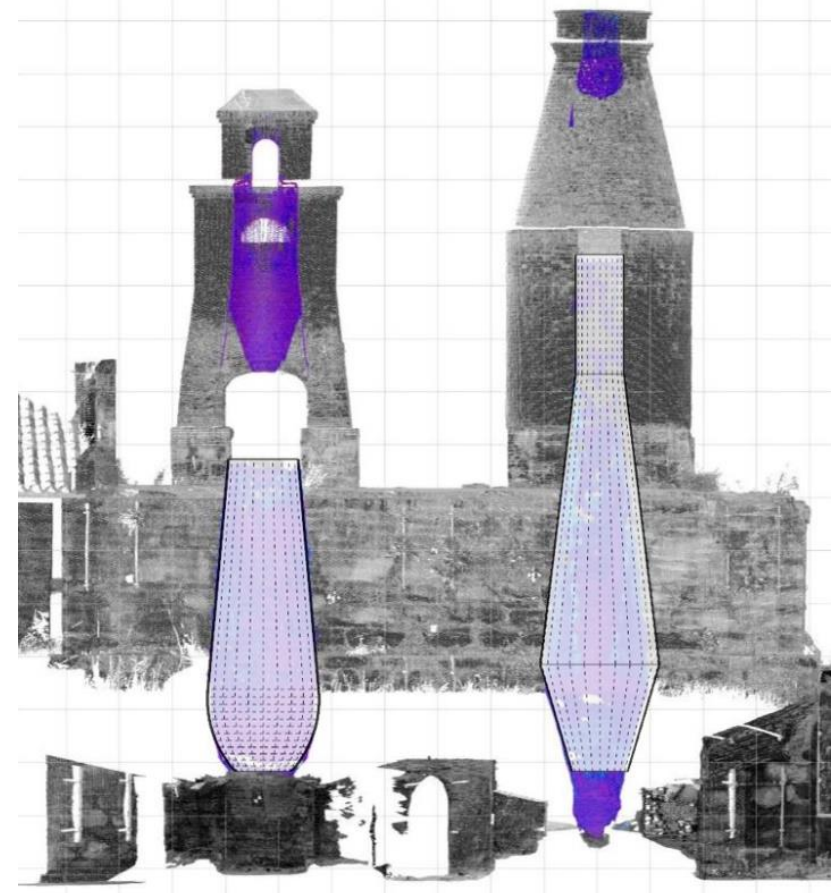

Figure 8: models of the two blast furnaces on raster base with $1 \mathrm{mx} 1 \mathrm{~m}$ grid (digital elaboration by the authors).

\section{CONCLUSIONS}

The design of the blasts was an unusual subject of study for the authors but thanks to the graphical analyses of the results it was possible to understand that the present work on the sections of the blast furnaces reconstructed from the database is only a fraction of what can be obtained also in terms of heritage enhancement and valorisation (Petrelli et al., 2013). Ipanema is the most important nucleus of development of technology in São Paulo before the railways. A large volume of material about the facility remains to be recovered, in national and local archives (Araujo et al., 2017). From the point of view of engineering history, it is very important to study and understand the technical, administrative, and political evolution of the Ipanema Iron Industry. At the same time taking into consideration the conservation perspective, digital technologies could be very useful to preserve and transfer to future generation these places as a learning place for academics and professionals (Cocchiarella, 2014).

Industrial historical sites are multifaceted entities that play a significant role in our social, geographical, cultural, and technological history. Their intricacy is the primary reason for the necessity for an interdisciplinary approach to study and evaluation, as well as a unique heritage management also based on digital tools. It is conceivable and necessary to employ cultural heritage enhancement measures in this circumstance. Due to the introduction of systems based on new technologies, particularly those based on extensive use ICT, this goal has become increasingly possible (De Carolis et al., 2018).

For abandoned industrial place it is possible the creation of programs that create adaptive cultural routes that may be used by a variety of users (Casillo et al., 2021). In addition to the technology aspect, approaches that communicate information material in an innovative and effective manner play a critical role.

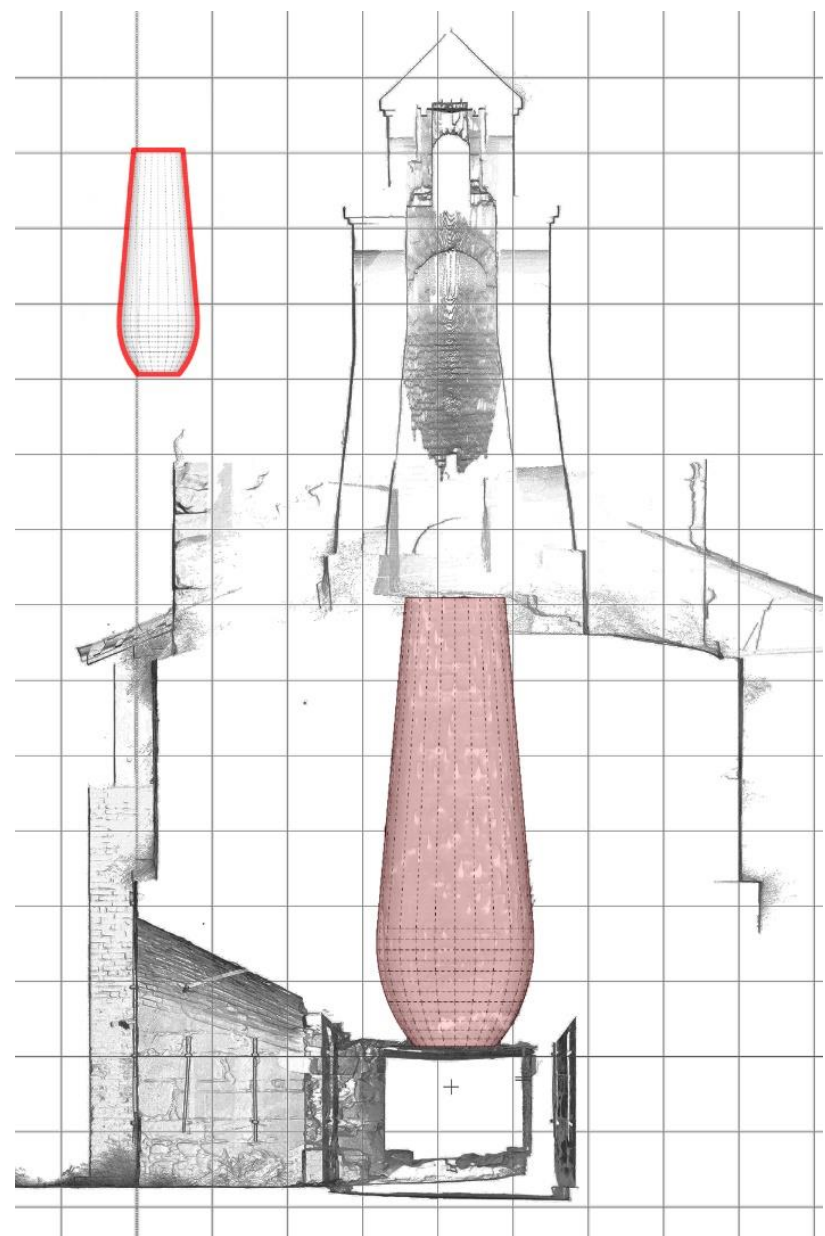

Figure 9: the south oven of Ipanema analysed by threedimensional tools (point cloud database and 3D model) with identification of inner void silhouette on $1 \mathrm{mx} 1 \mathrm{~m}$ grid (digital elaboration by the authors).

Everyone will be able to learn about or expand their understanding of the cultural locations that are most appropriate for them, which will be presented using the Digital Storytelling. Nowadays point cloud could be semantically enriched with advanced machine learning methods and new approaches are growing very fast also in the industrial cultural heritage sector (Teruggi et al., 2021, Malinverni et al., 2019). The association of heterogeneous information to 3D data by means of automated segmentation and classification methods can help to characterize, describe, and better interpret the object under study (Grilli et al., 2019), a perfect approach towards the valorisation of old industrial sites.

Could the Ipanema former industrial site become a place of knowledge end industrial memory preservation? The described research project will try to move more steps into this direction as soon as possible with more digital application and keeping the 
international multidisciplinary cooperation as a crucial factor for the success of this activity.

\section{ACKNOWLEDGEMENTS}

The authors would like to express their deeply gratitude to Prof. Fernando José Gomes Landgraf, Professor of the "Departamento de Engenharia Metalúrgica e de Materiais, Escola Politécnica, USP, São Paulo, SP" and at the time of this research President of the "Instituto de Pesquisas Tecnológicas do Estado de São Paulo" for the organization and support along the activity of digital documentation on site.

The research project carried out was made possible only by the hard work of his team and the staff of the DIAPReM centre at the University of Ferrara Department of Architecture.

Particularly our gratitude goes to Architect Daniele Felice Sasso (DIAPReM centre) who was the technician in charge of the digital documentation of the site.

\section{REFERENCES}

Andrade, F. D. C. D. D., 2015. A presença dos moinhos hidráulicos no Brasil. Anais do Museu Paulista: História e Cultura Material, 23, 133-193.

Araujo, P. E. M., de Lima Picanço, J., Faria, G., Zuffo, M. K., Balzani, M., Rossato, L., ... \& Landgraf, F. J. G. 2017. evolução do perfil interno dos altos fornos brasileiros do século XIX. In $47^{\circ}$ Seminário de Redução de Minério de Ferro e MatériasPrimas e $5^{\circ}$ Simpósio Brasileiro de Aglomeração de Minério de Ferro (Vol. 47, pp. 1-24).

Casillo M., Conte D., Lombardi M., Santaniello D., Valentino C. 2021. Recommender System for Digital Storytelling: A Novel Approach to Enhance Cultural Heritage. In: Del Bimbo A. et al. (eds) Pattern Recognition. ICPR International Workshops and Challenges. ICPR 2021. Lecture Notes in Computer Science, vol 12667. Springer, Cham.

Castronovo, V., 1980. L'industrializzazione italiana e la valorizzazione del patrimonio industriale, Mondadori, Milano.

Cocchiarella, L., 2014. Rilevare la forma, formare la conoscenza.

Giandebiaggi, P., Vernizzi, C., proceedings of XXXVI seminar UID, Parma 18-19-20 September 2014, Gangemi Publisher pp. 219-224.

De Berardinis, P., Devita, M., Palmero Iglesias, L. M., \& Trizio, I., 2019. Valorizzazione del patrimonio industriale del XX secolo: esperienze di riuso nella città di Valencia. Restauro Archeologico (Online), 27(2), 70-91.

De Carolis, B. N., Gena, C., Kuflik, T., Origlia, A., Raptis, G. E., 2018. AVI-CH 2018: Advanced Visual Interfaces for Cultural Heritage. In Proc. ACM Int. Conf. on Advanced Visual Interfaces.

Douet, J., 2013. Industrial Heritage Re-tooled: The TICCIH Guide to Industrial Heritage Conservation. Oxon: Routledge. p. 23.

Dupre, L., 1885. Memória sobre a Fábrica de Ferro de São João de Ipanema. Annaes da Escola de Minas de Ouro Preto, número 4, pag 37-68.
Falconer, K. 2006. The industrial heritage in Britain-the first fifty years. La revue pour l'histoire du CNRS, (14).

Fassi F., Mandelli A., Teruggi S., Rechichi F., Fiorillo F., Achille C. 2016. VR for Cultural Heritage. In: De Paolis L., Mongelli A. (eds) Augmented Reality, Virtual Reality, and Computer Graphics. AVR 2016. Lecture Notes in Computer Science, vol 9769. Springer, Cham.

Felicíssimo J.J., 1969. História da Siderurgia de São Paulo, Seus personagens, seus feitos. São Paulo: ABM, 1969.

Grilli E, Remondino F., 2019. Classification of 3D Digital Heritage. Remote Sensing. 11(7):847.

Ifko S., 2016, Comprehensive Management of Industrial Heritage Sites as A Basis for Sustainable Regeneration, « Procedia Engineering», 161, pp. 2040 - 2045.

La Duca, E., 2018. Augmented reality and virtual museums for the transmission and creation of knowledge: designing an app for the Alhambra as a case study. Proceedings of III Congreso de la Sociedad Internacional Humanidades Digitales Hispánicas Sociedades, políticas, saberes (Libro de resúmenes), vol. 18.

Landgraf, F.J.C., Araujo P.E.M., 2015. A arquitetura do altoforno e a biblioteca perdida de Ipanema: técnica e conhecimento no Brasil Joanino. Proceedings of Seminário nacional de história da ciência e da tecnologia, 14.,, 2014, Belo Horizonte. Anais Eletrônicos. São Paulo: SBHC, 2015. p. 1-15.

Landgraf, FJG Araújo PEM Schroeder R. Ipanema e os alemães. In: Kupfer, E. E. et al.. 2016. (Org.). Martius-Staden-Jahrbuch. 1ed.São Leopoldo: Oikos, 2016, v., p. 164-177.

Landgraf, F. J. G., Castro, A. H. F. D., Araujo, P. E., \& Regalado, L. B. 2021. Os canhões de Ipanema: tecnologia, indústria, logística e política em 1840. Anais do Museu Paulista: História e Cultura Material, 29.

Liu F., Zhao Q., Yang Y. 2018. An approach to assess the value of industrial heritage based on Dempster-Shafer theory, Journal of Cultural Heritage, Volume 32, 2018,

Pages 210-220.

Maia, R. R., Azevedo, C. R., \& Landgraf, F. J. 2012. Análise de inclusões de escória em amostras da fábrica de ferro de Ipanema. In $67^{\circ}$ Congresso ABM Internacional.

Martins Araujo, P., E., De Lima Picanço, J., Faria, G., Knörich Zuffo, M., Balzani, M., Rossato. L., Sasso, D. F., Gomes Landgraf, F., J., 2017. Evolução do perfil interno dos altos fornos brasileiros do século XIX. Proceedings of $47^{\circ}$ Seminário de Redução de Mirio de Ferro e Matérias-Primas, São Paulo, SP, Brasil.

Malinverni, E. S., Pierdicca, R., Paolanti, M., Martini, M., Morbidoni, C., Matrone, F., Lingua, A., 2019. Deep Learning for Semantic Segmentation of 3D Point Cloud. ISPRS Int. Arch. Photogramm. Remote Sens. Spatial Inf. Sci., XLII-2/W15, 735742 .

Morrison, T., Gu. N., Foulcher. N., Applying Augmented Reality to Preserving Industrial Heritage. Proceedings of international conference electronic Visualisation and the Arts (EVA 2012) DOI: 10.14236/ewic/EVA2012.30 
Teruggi, S., Grilli, E., Fassi, F., \& Remondino, F. (2021). 3D surveying, semantic enrichment and virtual access of large cultural heritage. ISPRS Annals of the Photogrammetry, Remote Sensing and Spatial Information Sciences, 8, 155-162.

Parisi, R., 2009. Industria, memoria, patrimonio. Per un'archeologia del riuso. Editoriale, «Patrimonio Industriale», a. III, n. 4, pp. 4-5, (03/19).

Petrelli, D., Ciolfi, L., Van Dijk, D., Hornecker, E., Not, E., \& Schmidt, A., 2013. Integrating material and digital: a new way for cultural heritage. interactions, 20(4), 58-63.

Spaziante, A., 2008. Patrimonio industriale e territorio. Ronchetta, C. \& Trisciuoglio, M. (eds.), Progettare per il patrimonio industriale, Torino, CELID.

Telles, P., 1983. História da Engenharia no Brasil: séculos XVI a XIX. Rio de Janeiro: Ed Livros Técnicos e Científicos.

Tomasevicius Filho, E. 2012. Entre a memória coletiva e a história de cola e tesoura: as intrigas e os malogros nos relatos sobre a fábrica de ferro de São João de Ipanema (Doctoral dissertation, Universidade de São Paulo).

Vitale, A., 2012, Luci e ombre sulla gestione del patrimonio industriale dismesso, «TECHNE», 03/2011, pp. 97-101. 